\title{
Role of Earthworm Allolobophora caliginosa in Enhancing Biological Control of Egyptian Cotton Leafworm Spodoptera littoralis by Steinernema carpocapsae and Heterorhabditis bacteriophora
}

\author{
El-Deeb A. M. and El-Ashry R. E \\ Plant Prot. Dept., Fac. Agric., Zagazig Univ., Egypt \\ Corresponding author email: Debo2012@yandex.ru
}

\begin{abstract}
Entomopathogenic nematodes, Steinernema carpocapsae (All strain) and Heterorhabditis bacteriophora (HP 88) dispersal were enhanced by the presence of earthworms that may serve as phoretic hosts based on increased IJs dispersal through the soil columns. IJs dispersal capability either in sandy or clayey soil is limited in the absence of earthworm Allolobophora caliginosa as compared with PVC column pipes that contained the earthworms. After two weeks, dispersal was estimated by using the greater wax moth, Galleria mellonella as bioassay organism. Results showed vertical dispersal of nematodes was increased significantly in the presence of earthworm as compared with soil columns in absence of earthworms. With two species of nematodes, when IJs were placed on the surface of soil columns, significantly more nematodes dispersed to the lower half of the columns when A. caliginosa was present and vice versa in the absence of earthworm. Thus, earthworm could be used as vectors to introduce/disperse beneficial organism. The current results showed that the ability of $S$. carpocapsae (All strain) and H. bacteriophora (HP 88) to control Egyptian cotton leafworm Spodoptera littoralis was enhanced in the presence of earthworm and caused significant S. littoralis suppression with mortality percentages 70 and $94 \%$ relative to the control in the absence of earthworm.
\end{abstract}

Key words: Earthworm, Nematode dispersal, Steinernema carpocapsae, Heterorhabditis bacteriophora, Spodoptera littoralis.

\section{INTRODUCTION}

Entomopathogenic nematodes (EPNs) belonging to families Heterorhabditidae and Steinernematidae are promising non-chemical alternatives for suppressing populations of insect pests in many crops worldwide (Kaya et al., 2006 and Georgis et al., 2006). They are widely distributed in natural and managed ecosystems of all continents except Antarctica (Adams et al., 2006). EPNs possess many attributes, an ideal biological control agents including safety (EPA exempt), ease of mass production, with high virulence and broad host range (Gaugler, 1981). The third stage infective juvenile (IJ) is the only stage that can reside in soil and infect a host. IJs have matualistic association with enteric bacteria i.e. Xenorhabdus spp. in the case of genus Steinernema and Photorhabdus spp. for the genus Heterorhaditis. The bacteria incorporate in the anterior intestine or in specific vesicles (Boemare, 2002). Persistence of EPNs populations after application showed rapid decline ranged 
between 40 to $90 \%$ within hours or days after application. It has been attributed to inactivation of IJs by ultraviolet light and desiccation at soil surface (Smits, 1996). On the other hand, density of IJs, dispersal capacity, IJs remaining energy reserves, tolerance against desiccation and temperature. interact with extrinsic factors such as biotic (i.e. predation, competition, phoretic relationships, synergistic and plant root) and abiotic (i.e. soil moisture, radiation, temperature, aeration, and soil characteristics). Moreover, phoretic relationships which can be considered beneficial through enhancing EPNs dispersal have been reported with earthworm (Shapiro et al., 1995), isopoda (Eng et al., 2005) and insects ( Kruitbos et al., 2009).

Earthworms are a major component of soil fauna communities in most ecosystems. They improve soil fertility by modification of soil structure, aeration, drainage and by breaking down and distributing organic matter (Edwards, 1983). Early studies revealed that EPNs can develop in previously damaged earthworms providing nematodes with alternate host in absence of more suitable insect hosts (Capinera et al., 1982; Nuutinen et al., 1991 and Potter et al.,1994). On the other hand, IJs could be transported by the setae of earthworm body and even looked inside the gut. Futhermore, EPNs can be ingested by earthworms and casts can have some viable EPNs but only in rare cases (Campos - Herrera et al., 2006). More recently, ShapiroIlan and Brown (2013) demonstrated lives how earthworms can improve nematode dispersal throughout the soil and this enhancing biocontrol.

The present study was conducted to determine dispersal of EPNs i.e. S.carpocapsae (ALL strain) and H.bacteriophora (HP88 strain) in the presence or absence of the earthworm Allolobophora caliginosa in soil columns, and their effect on enhancing control of Egyptian cotton leaf worm, Spodoptera littoralis Boisd under laboratory conditions.

\section{MATERIALS AND METHODS}

\section{Source, Rearing and Extraction of the tested animals}

\section{A. Entomogenous nematodes}

Infective juveniles (IJs) of Steinernema carpocapsae (All strain) and Heterorhabditis bacteriophora (HP88 strain) were obtained from Department of Entomology and Nematology, University of Florida, USA. The nematodes were cultured separately in last instar larvae of the greater wax moth, Galleria mellonella L. according to the technique described by Kaya \& Stock (1979). IJs were harvested and stored in distilled water at $12 \mathrm{C}$ for two weeks before experiment (Woodring and Kaya, 1988). On the other hand, at the end of each trial, IJs were extracted from soil samples using two methods according to Sturhan \& Mracek (2000). In the first method, sieving technique which is commonly applied for extraction plant-parasitic nematodes (Southey, 1986) in which 60 and 350 mesh sieves were employed, and Baermann trays were used to separate nematodes from soil particles. The obtained nematode suspension was examined with a research microscope and nematodes were counted using Hawksely slide. In the second method, soil samples were placed in small plastic containers measuring 22x $18 \times 12 \mathrm{~cm}$ and healthy G. mellonella larvae were added as bait for IJs. After 48 hours, dead larvae were recovered and examined under stereomicroscope for the presence of EPNs.

\section{B.Greater wax moth, Galleria mellonella L.}


Naturally infested combs with G.mellonella were obtained from honey in Zagazig University. The collected larvae were reared using an artificial medium consisted of honey, wheat bran, glycerol, soy flour, milk powder, dry yeast and honey bee was in glass jars kept under laboratory conditions at $24 \pm 3^{\circ} \mathrm{C}$. (Ekmen et al., 2010). Each jar was provided with a tissue paper as a physical surface for moths to lay their eggs. The egg masses were transferred frequently to new glass jars containing the nutrient medium. Enough quantity of $G$. mellonella larvae were collected by repeating this technique.

\section{Earthworm, Allolobophora caliginosa}

The earthworms were collected from clayey soil cultured with horse manure at Zagazig district, Sharkia governorate by digging and hand sorting using hand trowel. The collected earthworms were identified to generic level according to the key given by Edwards \& Lofty (1976). Earthworms of A. caliginosa were cultured under laboratory conditions using clayey soil to a depth of about $40 \mathrm{~cm}$ - diameter. The pots were filled with clayey soil to a depth of about $25 \mathrm{~cm}$. Ten adults of equal size of the same species were introduced on the top of the soil in each pot. Tap water was sprinkled on each pot content to keep the culture moistened but not was spread on the top of each pot at weekly intervals and covered with thin layer of clayey soil. The harvested earthworms were used in the experiments (Ibrahim et al.,2010).

Experiment 1. Vertical movement of $S$. carpocapsae (All strain) and $H$. bacteriophora (HP88 strain) in clayey and sandy soils with or without earthworms

Soil columns consisted of jointed six 5-cm- long sections of $5-\mathrm{cm}$ diameter polyvinyl chloride (PVC), were used as described by Shapiro et al.(1993). Columns were filled with sterilized soil to bulk density of 1.9 and $1.2 \mathrm{~g} / \mathrm{cm} 3$ for clay and sandy soil, respectively. Clayey soil was obtained from the upper $20 \mathrm{~cm}$ in the Experimental farm, Faculty of Agriculture, Zagazig University, while sandy soil was collected by the same manner from newly reclaimed sandy area located in El-Salhiya district, Sharkia Governorate. The mechanical analysis of sandy soil was as follows: $(95.7 \%$ sand; $1.2 \%$ silt and $3.1 \%$ clay), while the parallel values for clayey soil were 3.64 $\%, 58.73 \%$ and $37.63 \%$, respectively. Each soil was autoclaved and left for one week before experiment. Soil moisture was adjusted to field capacity in each column (18\%). About $40 \mathrm{~g}$ of dried cow manure were placed on the top of each column earthworm treatments. Column of each soil type received one of the following treatments, downward and upward movement of S.carpocapsae and H. bacteriophora in the presence or absence of the earthworm, A.caliginosa. Each treatment was replicated three times. Therefore, 24 columns were needed for each soil type. In the treatments of earthworms, two adults of A.caliginosa were placed on the surface of columns and allowed to burrow for one week before the addition of nematodes (Shapiro et al.,1993).

In treatments of the downward movement, 5000 IJs of S.carpocapsae (All strain) and H. bacteriophora (HP88 strain) were placed in $0.5 \mathrm{ml}$ water to one hole of about $1-\mathrm{cm}$ wide to the surface of each soil column. Literature reports indicated that S.carpocapsae move upward from the placement site in the soil, while $H$. bacteriophora tend to migrate downward in the soil. Therefore, to stimulate downward movement of IJs , 2-6 moth larvae were put in screen bait cage measuring $2.5 \times 3 \mathrm{~cm}$ and placed on the bottom end of each column. On the other hand, to test upward movement, the same numbers of the above-mentioned nematodes 
were applied in $0.5 \mathrm{ml}$ water to soil on the bottom of each column $(30 \mathrm{~cm}$ below the soil surface). Two weeks later, soil columns were examined for larvae mortality. The soil of each $5 \mathrm{~cm}$ long section of PVC pipe was subdivided into two equal parts each of $115 \mathrm{gm}$. The first was processed for IJs extraction as mentioned before, while the second once was placed in plastic tray $(18 \times 12 \times 8 \mathrm{~cm})$ and provided with 10 fresh $G$. mellonella larvae. The plastic trays were kept at $28{ }^{\circ} \mathrm{C}$ in the laboratory for 3 days, thereafter numbers of dead larvae were recorded to estimate percentage of mortality.

Experiment 2. Enhancing biocontrol of Egyptian cotton leafworm, Spodoptera littoralis by earthworm $A$. caliginosa and entomogenous nematodes

This experiment was conducted to evaluate the phoretic role of earthworm $A$. caliginosa in controlling Egyptian cotton leafworm $S$. littoralis by two entomopathogenic nematodes i.e S. carpocapsae (All strain) and H.bacteriophora (strain HP88). The experiment work was carried out in plastic pots $(5 \mathrm{~cm}$ - diameter, $30 \mathrm{~cm}$ deep ), filled with $1185 \mathrm{~g}$ autoclaved clayey soil gained from Experimental Farm , Faculty of Agriculture, Zagazig University. Mechanical analysis of soil used was above-mentioned.

Nearly $309 \mathrm{ml}$ of tap water were added to pots in order to achieve moisture of field capacity. One hole of $1 \mathrm{~cm}$ diameter and $1 \mathrm{~cm}$ deep was in the center of each pot. About 5000 IJs of $S$. carpocapsae or H.bacteriophora in $2 \mathrm{ml}$ tap water were pipetted onto the hole. Four adults of $A$. caliginosa combined with $40 \mathrm{~g}$ of dried cow manure were placed on the top of each earthworm treatment. Ten $5^{\text {th }}$ instar larvae of $S$. littoralis were put on soil surface together with 5 leaves of Egyptian clover, Trifolium alexandrina as natural diet for insects. Pots were sealed with perforated upper lid to prevent insects from escaping. The pots were arranged on a bench in a completely randomized design with four treatments, each with five replicates and were left for two weeks before testing insect mortality.

Larval mortality was checked at $24 \mathrm{~h}$ interval up to $72 \mathrm{~h}$. Dead larvae were removed, rinsed in distilled water and placed individually in small Petri dishes of $5 \mathrm{~cm}$ diameter lined with moist filter paper. After 3 days cadavers were dissected under a stereomicroscope to confirm the presence of nematodes. Average room temperature and relative humidity during experiments were $29 \pm 3{ }^{\circ} \mathrm{C}$ and $78 \%$, respectively. S.littoralis was reared on castor plant (Ricinus communis). Egg clutches were collected from infested cotton field. Eggs were reared in separate jars and fresh surface sterilized castor leaves were provided. Cleaning, changing of food and chining of culture were done at regular intervals to get healthy culture. The containers were sealed with parafilm to prevent dehydration and left in bench at $25 \pm 3{ }^{\circ} \mathrm{C}$ during rearing period.

\section{Statistical analysis}

Movements of nematodes in sandy and clayey soils were compared using a Student Paired Sample a t-test. Data on mortality of S.littoralis were selected to analysis of variance using F test. Means were compared by Duncan's multiple range test at 5\% level of possibility according to Snedecor (1966).

\section{RESULTS AND DISCUSSION}

Samples were collected at different column depth to recover infective juveniles of S.carpocapsae in the presence and absence of earthworm, A. caliginosa. Data in 
Table (1) showed the effect of $A$. caliginosa on downward and upward movement of S.carpocapsae IJs. In upward movement percentage of IJs recovered from different column depth decreased significantly from 83.38 (0-5cm deep) to 4.35 at $10-15 \mathrm{~cm}$ deep and reach 0.00 at $15-30 \mathrm{~cm}$ deep in the absence of earthworm A. caliginosa in sandy soil. Whereas, the percentage of IJs recovered in the presence of $A$. caliginosa was increased significantly from $1.39(10-15 \mathrm{~cm}$ deep) to $7.90(15-20 \mathrm{~cm}$ deep) and significantly farther downward (90.88) at the depth of $20-25 \mathrm{~cm}$.

On the other hand, downward dispersal of $S$. carpocapsae was significantly increased farther in the presence of $A$. caliginosa. Percentage of IJs recovered were 4.77 and 5.81 at column depth $10-15$ and $5-10 \mathrm{~cm}$, respectively in the presence $A$. caliginosa earthworms, whereas in the absence of earthworm, percentage of IJs decreased from 6.13 to 2.32 and 0.67 at the column depth $15-20,10-15$ and $5-10 \mathrm{~cm}$, respectively. At column depth $0-5 \mathrm{~cm}$, upward dispersal of $S$. carpocapsae was increased significantly to reach 78.26 in the presence of earthworm, whereas no IJs was found in the absence of $A$. caliginosa.

Data in Table (1) clearly showed the higher dispersal percentage (91.84\%) of S.carpocapsae at column depth $20-25 \mathrm{~cm}$ in the presence of earthworm A. caliginosa in clayey soil. Whereas in the absence of $A$. caliginosa, percentages of IJs dispersal were 6.87 and 1.45 at column depths $5-10$ and $10-15 \mathrm{~cm}$ only. So, presence of earthworm, A. caliginosa caused higher percentages of IJs dispersal at deeper column than other columns. With downward movement the percentages of IJs recovered in the presence of earthworm were 5.13, 5.69 and 73.18 at column depth 15-20, 20-25 and $25-30 \mathrm{~cm}$, respectively. At 5-10 cm depth, IJs recovered was 0.27 in the presence of $A$. caliginosa and 0.00 in the absence of $A$. caliginosa. When no earthworm found, dispersal of IJs of S.carpocapsae decreased significantly 14 days post- treatment.

The percentage of IJs of $H$. bacteriophora dispersal in absence or presence of the earthworm, A. caliginosa in sandy soil is shown in Table (2). In upward movement, data revealed that $A$. caliginosa increased the percentage of IJs dispersal through the top of column depth 0-5, 5-10 and 10-15 $\mathrm{cm}$ whereas in the absence of earthworm, IJs of $H$. bacteriophora tend to move towards the bottom of column depth. The percentages of IJs recovered were 2.81, 4.94 and 89.77 at column depth $15-20,20-25$ and $25-30 \mathrm{~cm}$ in the absence of earthworm.

In the presence of $A$. caliginosa, recovered infective juveniles of $H$. bacteriophora were $31.23,33.30$ and 33.66 at column depth $0.5,5-10$ and $10-15 \mathrm{~cm}$, respectively. In downward movement, recovered IJs samples show that $H$. bacteriophora moved further upward in the presence of earthworm A. caliginosa in sandy soil. The percentage of IJs of H. bacteriophora was $79.18,6.16$ and 4.70 at column depth 0-5, 5-10 and 10-15, respectively. In the absence of earthworm $A$. caliginosa IJs of $H$. bacteriophora moved to bottom of column depth at 30-25, 20- 25 and $15-20 \mathrm{~cm}$ with percentages of $1.60,3.43$ and 92.11 , respectively. With upward movement the highest percentage of $H$. bacteriophora IJs (93.31) was recovered from the top surface of clayey soil columns (0-5 deep) in the presence of the earthworm, $A$. caliginosa. However, no IJs of $H$. bacteriophora were recovered at depth 0-5, 5-10 and $10-15 \mathrm{~cm}$ in the absence of A.caliginosa. 
Table 1. Percentage of nematodes recovered from sandy and clayey soil columns testing downward or upward movement of Steinernema carpocapsae (All strain) in the presence and absence of the earthworm, Allolobophora caliginosa.

\begin{tabular}{|c|c|c|c|c|c|c|c|c|}
\hline \multirow{4}{*}{$\begin{array}{c}\text { Column depth/ } \\
\mathrm{cm}\end{array}$} & \multicolumn{8}{|c|}{ S. carpocapsae } \\
\hline & \multicolumn{4}{|c|}{ Sandy soil } & \multicolumn{4}{|c|}{ Clayey soil } \\
\hline & \multicolumn{2}{|c|}{ Upward movement } & \multicolumn{2}{|c|}{ Downward movement } & \multicolumn{2}{|c|}{ Upward movement } & \multicolumn{2}{|c|}{ Downward movement } \\
\hline & $\begin{array}{c}\text { No } \\
\text { Earthworm }\end{array}$ & $\begin{array}{c}\text { With } \\
\text { Earthworm. }\end{array}$ & $\begin{array}{c}\text { No } \\
\text { Earthworm }\end{array}$ & $\begin{array}{c}\text { With } \\
\text { Earthworm. }\end{array}$ & $\begin{array}{c}\text { No } \\
\text { Earthworm }\end{array}$ & $\begin{array}{c}\text { With } \\
\text { Earthworm. }\end{array}$ & $\begin{array}{c}\text { No } \\
\text { Earthworm }\end{array}$ & $\begin{array}{c}\text { With } \\
\text { Earthworm. }\end{array}$ \\
\hline $0-5$ & $83.38 \mathrm{a}$ & $0.00 \mathrm{c}$ & $0.00 \mathrm{c}$ & $78.26 \mathrm{a}$ & $92.01 \mathrm{a}$ & $0.00 \mathrm{c}$ & $0.00 \mathrm{c}$ & $0.00 \mathrm{c}$ \\
\hline $5-10$ & $34.13 \mathrm{~b}$ & $0.00 \mathrm{c}$ & $0.67 \mathrm{c}$ & $5.81 \mathrm{~b}$ & $6.87 \mathrm{~b}$ & $0.00 \mathrm{c}$ & $0.00 \mathrm{c}$ & $0.27 \mathrm{c}$ \\
\hline $10-15$ & $4.35 \mathrm{bc}$ & $1.39 \mathrm{c}$ & $2.33 \mathrm{bc}$ & $4.77 \mathrm{~b}$ & $1.46 \mathrm{c}$ & $0.00 \mathrm{c}$ & $0.13 \mathrm{c}$ & $1.50 \mathrm{bc}$ \\
\hline $15-20$ & $0.00 \mathrm{c}$ & $7.90 \mathrm{~b}$ & $6.13 \mathrm{bc}$ & $1.29 \mathrm{c}$ & $0.00 \mathrm{c}$ & $1.39 \mathrm{c}$ & $1.57 \mathrm{~b}$ & $5.13 \mathrm{~b}$ \\
\hline $20-25$ & $0.00 \mathrm{c}$ & $90.88 \mathrm{a}$ & $7.41 \mathrm{~b}$ & $0.12 \mathrm{c}$ & $0.00 \mathrm{c}$ & $6.41 \mathrm{~b}$ & $3.61 \mathrm{~b}$ & $5.69 \mathrm{~b}$ \\
\hline $25-30$ & $0.00 \mathrm{c}$ & $0.00 \mathrm{c}$ & $64.23 \mathrm{a}$ & $0.00 \mathrm{c}$ & $0.00 \mathrm{c}$ & $91.84 \mathrm{a}$ & $84.56 \mathrm{a}$ & $73.18 \mathrm{a}$ \\
\hline
\end{tabular}

Numbers represent means of three replications. Means followed by the same letter are not significantly different at $\mathrm{P} \leq 0.05$.

Table 2. Percentage of nematodes recovered from sandy and clayey soil columns testing downward or upward movement of Heterorhabditis bacteriophora (HP88) in the presence and absence of the earthworm, Allolobophora caliginosa.

\begin{tabular}{|c|c|c|c|c|c|c|c|c|}
\hline \multirow{4}{*}{ Column depth/ $\mathrm{cm}$} & \multicolumn{8}{|c|}{ H. bacteriophora } \\
\hline & \multicolumn{4}{|c|}{ Sandy soil } & \multicolumn{4}{|c|}{ Clayey soil } \\
\hline & \multicolumn{2}{|c|}{ Upward movement } & \multicolumn{2}{|c|}{ Downward movement } & \multicolumn{2}{|c|}{ Upward movement } & \multicolumn{2}{|c|}{ Downward movement } \\
\hline & $\begin{array}{c}\text { No } \\
\text { Earthworm }\end{array}$ & $\begin{array}{c}\text { With } \\
\text { Earthworm. }\end{array}$ & $\begin{array}{c}\text { No } \\
\text { Earthworm }\end{array}$ & $\begin{array}{c}\text { With } \\
\text { Earthworm. }\end{array}$ & $\begin{array}{c}\text { No } \\
\text { Earthworm }\end{array}$ & $\begin{array}{c}\text { With } \\
\text { Earthworm. }\end{array}$ & $\begin{array}{c}\text { No } \\
\text { Earthworm }\end{array}$ & $\begin{array}{c}\text { With } \\
\text { Earthworm. }\end{array}$ \\
\hline $0-5$ & $0.00 \mathrm{~d}$ & $31.23 \mathrm{a}$ & $0.00 \mathrm{c}$ & $79.18 \mathrm{a}$ & $0.00 \mathrm{~b}$ & $93.31 \mathrm{a}$ & $0.00 \mathrm{c}$ & $76.54 \mathrm{a}$ \\
\hline $5-10$ & $0.00 \mathrm{~d}$ & $33.30 \mathrm{a}$ & $0.00 \mathrm{c}$ & $6.16 \mathrm{~b}$ & $0.00 \mathrm{~b}$ & $3.09 \mathrm{~b}$ & $0.00 \mathrm{c}$ & $6.53 \mathrm{~b}$ \\
\hline $10-15$ & $0.00 \mathrm{~d}$ & $33.66 \mathrm{a}$ & $0.25 \mathrm{c}$ & $4.70 \mathrm{~b}$ & $0.00 \mathrm{~b}$ & $2.00 \mathrm{~b}$ & $0.09 \mathrm{c}$ & $7.42 \mathrm{~b}$ \\
\hline $15-20$ & $2.81 \mathrm{c}$ & $0.00 \mathrm{~b}$ & $1.60 \mathrm{bc}$ & $2.55 \mathrm{c}$ & $2.64 \mathrm{~b}$ & $0.00 \mathrm{c}$ & $0.49 \mathrm{c}$ & $0.94 \mathrm{c}$ \\
\hline $20-25$ & $4.94 \mathrm{~b}$ & $0.00 \mathrm{~b}$ & $3.43 \mathrm{~b}$ & $0.81 \mathrm{~cd}$ & $3.13 \mathrm{~b}$ & $0.00 \mathrm{c}$ & $3.04 \mathrm{~b}$ & $0.41 \mathrm{c}$ \\
\hline $25-30$ & $89.77 \mathrm{a}$ & $0.00 \mathrm{~b}$ & $92.11 \mathrm{a}$ & $0.00 \mathrm{~d}$ & $62.27 \mathrm{a}$ & $0.00 \mathrm{c}$ & $92.76 \mathrm{a}$ & $0.00 \mathrm{c}$ \\
\hline
\end{tabular}

Numbers represent means of three replications. Means followed by the same letter are not significantly different at $\mathrm{P} \leq 0.05$. 
At more depths, percentage of IJs recovered were increased in absence of earthworm to reach 62.27 at depth $25-30 \mathrm{~cm}$ whereas, at the same depth no IJs was extracted in the presence of $A$. caliginosa (Table 2). With downward movement, earthworms have increased percentage of IJs recovered from depth 10-15, 5-10 and 0-5 cm to reach 7.42, 6.53 and 76.54, respectively. In the absence of earthworm, A. caliginosa IJs of $H$. bacteriophora tend to move downward of column depth and sharply reached its maximum (92.76\%) at 25-30 deep. No infective juveniles were extracted from depths $0-5$ and $5-10 \mathrm{~cm}$.

Data in Table (3) show the mortality percentage in G. mellonella larvae exposed to S.carpocapsae isolated from each column section. Generally, number of dead larvae was higher in sandy soil than clayey soil in presence or absence of earthworms. In sandy soil, where no earthworm was found number of dead larvae in downward movement was greater in the top of soil columns sections, $0-5 \mathrm{~cm}, 5-10$ and $10-15 \mathrm{~cm}$ to reach $14.33,16.33$ and 17.00 , respectively. Whereas, in the presence of earthworm was $12.00,15.00$ and 16.33 with the above-mentioned soil column sections. Earthworm increased numbers of dead G. mellonella larvae in the bottom of soil columns sections $15-20$ and $20-25 \mathrm{~cm}$ to reach 9.67 and 1.67 while in the absence of earthworm, no dead G. mellonella larvae was observed at 20-30cm deep. In upward movement, earthworm encourage $S$. carpocapsae to move up to the top of soil columns sections $5-10$ and $15-15 \mathrm{~cm}$ whereas at the same sections, no IJs of $S$. carpocapsae were found and no dead G. mellonella larvae was observed.

In clayey soil, although the nematodes dispersed farther downward with earthworms and increased number of dead G. mellonella larvae, numbers of dead larvae were lower than in sandy soil in all soil columns sections. Numbers of dead $G$. mellonella larvae were $10.00,12.00,14.007 .33$ and 0.67 at soil column depths $0-5$, $5-10,10-15,15-20$ and $20-25 \mathrm{~cm}$. whereas at $25-30 \mathrm{~cm}$ soil column depth no $G$. mellonella larvae was observed either in presence or absence of earthworms. In upward dispersal, earthworms encourage IJs of $S$. carpocapsae to move up to near the top of soil columns and reach to $10-15$ and $5-10 \mathrm{~cm}$ sections. The dead G. mellonella larvae were 1.33 and 0.67 at soil columns depth $10-15$ and $5-10 \mathrm{~cm}$ whereas, in the absence of earthworms, at above-mentioned depth the dead G. mellonella larvae were 0.0 for each.

Data in table (4) indicated that when earthworms were found, the nematode significantly dispersed to top column sections and more dead G. mellonella larvae were observed. Dismantled sandy and clayey soil columns sections and observed mortality in $G$. mellonella larvae were assessed after 14 days. In sandy soil, numbers of dead larvae caused by H. bacteriophora (HP88) and earthworm's treatments were increased as compared to treatments without earthworms. In downward movement, number of dead larvae was greater in treatments with earthworms than in their absence. Numbers of recovered dead larvae of G.mellonella were 2.67, 10.67 and 14.00 at soil columns sections, 5-10, $10-15$ and $15-20 \mathrm{~cm}$, respectively. Whereas, in absence of earthworm was $0.00,3.33$ and 11.33 with the same soil column sections. In upward dispersal treatments with H. bacteriophora (HP88) earthworm increased numbers of dead G. mellonella larvae in the soil columns sections $15-20$ and $20-25 \mathrm{~cm}$ to reach 8.33 and 4.00 , respectively while at the same depth sections in absence of earthworm numbers of dead G. mellonella larvae were 6.33 and 0.0 , respectively. 
Table 3. Number of dead Galleria mellonella larvae recovered from soil column sections infected with Steinernema carpocapsae (All strain) in the presence and absence of earthworm (Allolobophora caliginosa).

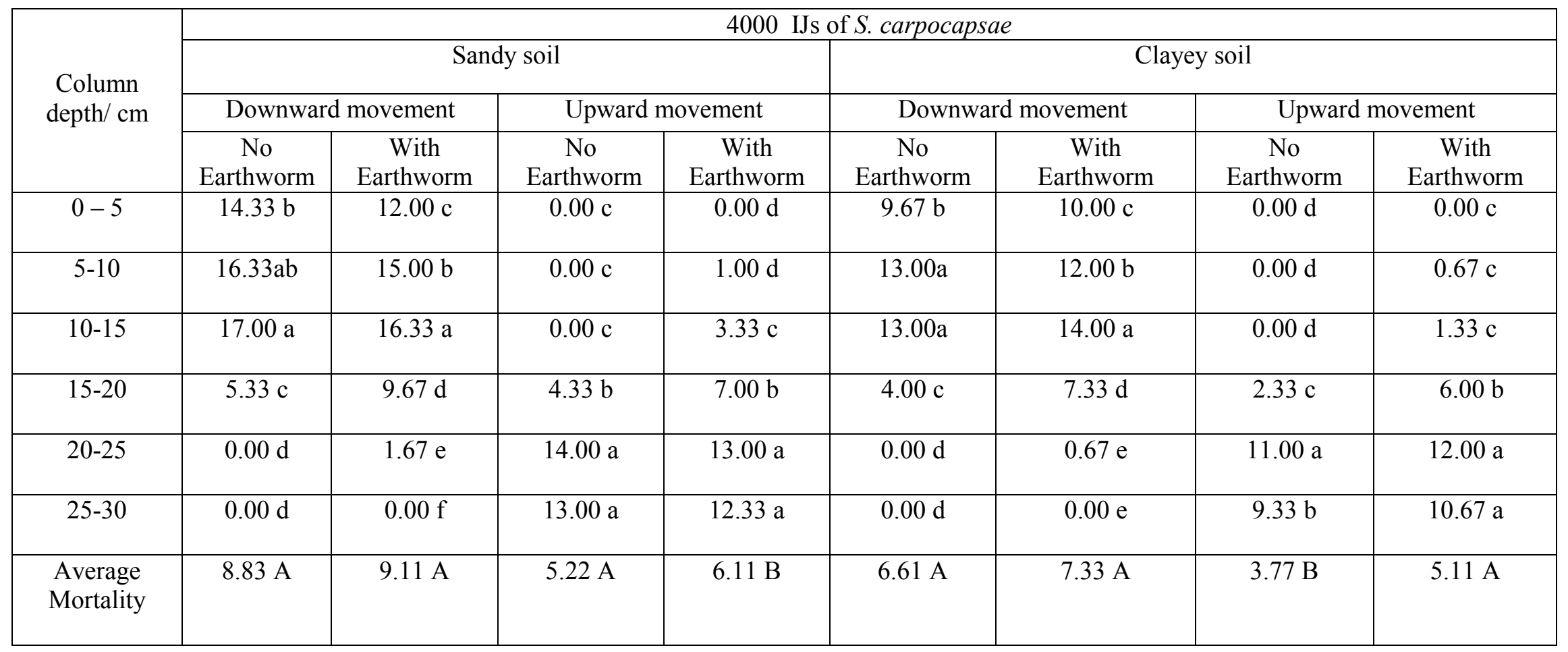

Numbers represent means of three replications. The same lowercase letter in columns or uppercase letters in rows indicate no significant differences at $\mathrm{P} \leq 0.05$ according to Duncan's multiple range test. Steinernema carpocapsae was introduced on top of soil columns in the upward and downward dispersal experiments. Twenty G. mellonella larvae were exposed to soil removed from column sections 2 weeks after nematodes introduction. G. mellonella mortality indicates relative nematode densities. 
In clayey soil although, the earthworm improved the nematodes dispersal up to the half top of soil columns sections and increased numbers of dead G. mellonella larvae, numbers of dead larvae in downward movement still lower than in upward movement. Numbers of dead G. mellonella larvae in treatments with earthworms were 0.00, 7.00; $1.33,11.00$ and $6.67,12.67$ at sections depth $0-5,5-10$ and $10-15 \mathrm{~cm}$ with downward and upward, respectively.

Entomopathogenic nematodes are considered as good bio-agents for controlling cotton leafworm, S.littoralis (Saleh \& Ragab, 1999 and Hussein, 2004). In the present investigation a significant $(\mathrm{P} \leq 0.05)$ percentage of mortality of $S$. littoralis was recorded by S.carpocapsae (70\%) and H. bacteriophora $(94 \%)$ in the presence of the earthworm, A. calginosa compared to control (without earthworm) (Fig.1). Its effect could be related to the interaction between entomogenous nematodes and earthworm during upward and downward movement (Poinar, 1978; Timper et al., 1988 and Shapiro et al., 1993). Soil texture and moisture (Molyneux and Bedding, 1984 and Wang et al., 1995) also play a vital role in this aspect.

EPNs disperse horizontally and vertically throughout the soil. Active dispersal of IJs by their own energy after inundative application is limited and differs from one species to another. It is usually a few centimeters per day and limited to scale of meters overall (Downes \& Griffin, 1996 and Poinar \& Hom (1986). Light- textured (sand) soil favor nematode movement (Georgis \&Poinar, 1983 and Koppenhofer \&Fuzy, 2006). S. carpocapsea IJs move upward in soil column under laboratory conditions, whereas S. glaseri and H.bacteriophora move downwards (Georgis \& Poinar, 1983 and Schroeder \& Beavers, 1987). Heterorhabditis spp. tended to migrate farther than did Steinernema spp. in soil arenas (Westerman, 1995; Downes \& Griffin, 1996 and Koppenhofer \& kaya, 1996). Natural populations of S.carpocapsae were found in upper 1-2 cm of the soil, whereas H.bacteriophora was detected through the upper $8 \mathrm{~cm}$ of soil (Campbell et al., 1995). When Ferguson et al. (1995) compared vertical distribution of certain EPN species, it was found that S.carpocapsae and undescribed Steinernema sp. remained near the soil surface, while H.bacteriophora move to greater depths.

The present study gave evidence that earthworm A.caliginosa may serve as phoretic host of S. carpocapsae (All strain) and H.bacteriophora (HP88). Nematodes may be dispersed on the surface of earthworms, or may be passed through the earthworm digestive system and remain viable (Shapero et al., 1995). Mortality percentages of S.littoralis were more pronounced with H.bacteriophora than did S.carpocapsae in the presence of A.caliginosa.

Entomopathogenic nematodes genera i.e. Steinernema and Heterorhabditis are used as biological control agents. They have a wide host range, are safety way for nontarget organisms, vectoring a bacterium, Xenorhabdus sp. and Photorhabdus sp., which precipitately kills the insect hosts (kaya and Gaugler 1993). In spite of their good prospective as biological control agents, results applications of nematode have been changefully. Biotic and abiotic factors that impact the efficacy of applications nematode must be scrutinized (Molyneux and Bedding, 1984). 
Table 4. Number of dead Galleria mellonella larvae recovered from soil column sections infected with Heterorhabditis bacteriophora (HP88) in the presence and absence of earthworm (Allolobophora caliginosa).

\begin{tabular}{|c|c|c|c|c|c|c|c|c|}
\hline \multirow{4}{*}{$\begin{array}{l}\text { Column } \\
\text { depth/cm }\end{array}$} & \multicolumn{8}{|c|}{4000 IJs of $H$. bacteriophora } \\
\hline & \multicolumn{4}{|c|}{ Sandy soil } & \multicolumn{4}{|c|}{ Clayey soil } \\
\hline & \multicolumn{2}{|c|}{ Downward movement } & \multicolumn{2}{|c|}{ Upward movement } & \multicolumn{2}{|c|}{ Downward movement } & \multicolumn{2}{|c|}{ Upward movement } \\
\hline & $\begin{array}{c}\text { No } \\
\text { Earthworm }\end{array}$ & $\begin{array}{c}\text { With } \\
\text { Earthworm }\end{array}$ & $\begin{array}{c}\text { No } \\
\text { Earthworm }\end{array}$ & $\begin{array}{c}\text { With } \\
\text { Earthworm }\end{array}$ & $\begin{array}{c}\text { No } \\
\text { Earthworm }\end{array}$ & $\begin{array}{c}\text { With } \\
\text { Earthworm }\end{array}$ & $\begin{array}{c}\text { No } \\
\text { Earthworm }\end{array}$ & $\begin{array}{c}\text { With } \\
\text { Earthworm }\end{array}$ \\
\hline $0-5$ & $0.00 \mathrm{~d}$ & $0.00 \mathrm{~d}$ & $11.67 \mathrm{~b}$ & $9.00 \mathrm{c}$ & $0.00 \mathrm{c}$ & $0.00 \mathrm{~d}$ & $7.00 \mathrm{c}$ & $7.00 \mathrm{c}$ \\
\hline $5-10$ & $0.00 \mathrm{~d}$ & $2.67 \mathrm{~d}$ & $17.00 \mathrm{a}$ & $15.33 \mathrm{~b}$ & $0.00 \mathrm{c}$ & $1.33 \mathrm{~d}$ & $10.00 \mathrm{~b}$ & $11.00 \mathrm{~b}$ \\
\hline $10-15$ & $3.33 \mathrm{c}$ & $10.67 \mathrm{c}$ & $18.00 \mathrm{a}$ & $18.00 \mathrm{a}$ & $0.67 \mathrm{c}$ & $6.67 \mathrm{c}$ & $13.00 \mathrm{a}$ & $12.67 \mathrm{a}$ \\
\hline $15-20$ & $11.33 \mathrm{~b}$ & $14.00 \mathrm{~b}$ & $6.33 \mathrm{c}$ & $8.33 \mathrm{c}$ & $4.67 \mathrm{~b}$ & $10.33 \mathrm{~b}$ & $5.00 \mathrm{c}$ & $3.00 \mathrm{~d}$ \\
\hline $20-25$ & $17.33 \mathrm{a}$ & $17.67 \mathrm{a}$ & $0.00 \mathrm{~d}$ & $4.00 \mathrm{~d}$ & $10.67 \mathrm{a}$ & $13.67 \mathrm{a}$ & $2.33 \mathrm{~d}$ & $0.00 \mathrm{e}$ \\
\hline $25-30$ & $16.00 \mathrm{a}$ & $13.00 \mathrm{bC}$ & $0.00 \mathrm{~d}$ & $0.00 \mathrm{E}$ & $11.67 \mathrm{a}$ & $11.67 \mathrm{~b}$ & $0.00 \mathrm{e}$ & $0.00 \mathrm{e}$ \\
\hline
\end{tabular}

*Numbers represent means of three replications. Heterorhabditis bacteriophora was introduced $30 \mathrm{~cm}$ below the soil surface in the upward dispersal experiment and on the soil surface in the downward dispersal experiment. Twenty $G$. mellonella larvae were exposed to soil removed from column sections 2 weeks after nematodes introduction. G. mellonella mortality indicates relative nematode densities. * The same lowercase letter in columns or uppercase letter in rows indicates no significant differences at $\mathrm{P} \leq 0.05$ according to Duncan's multiple range tests. 


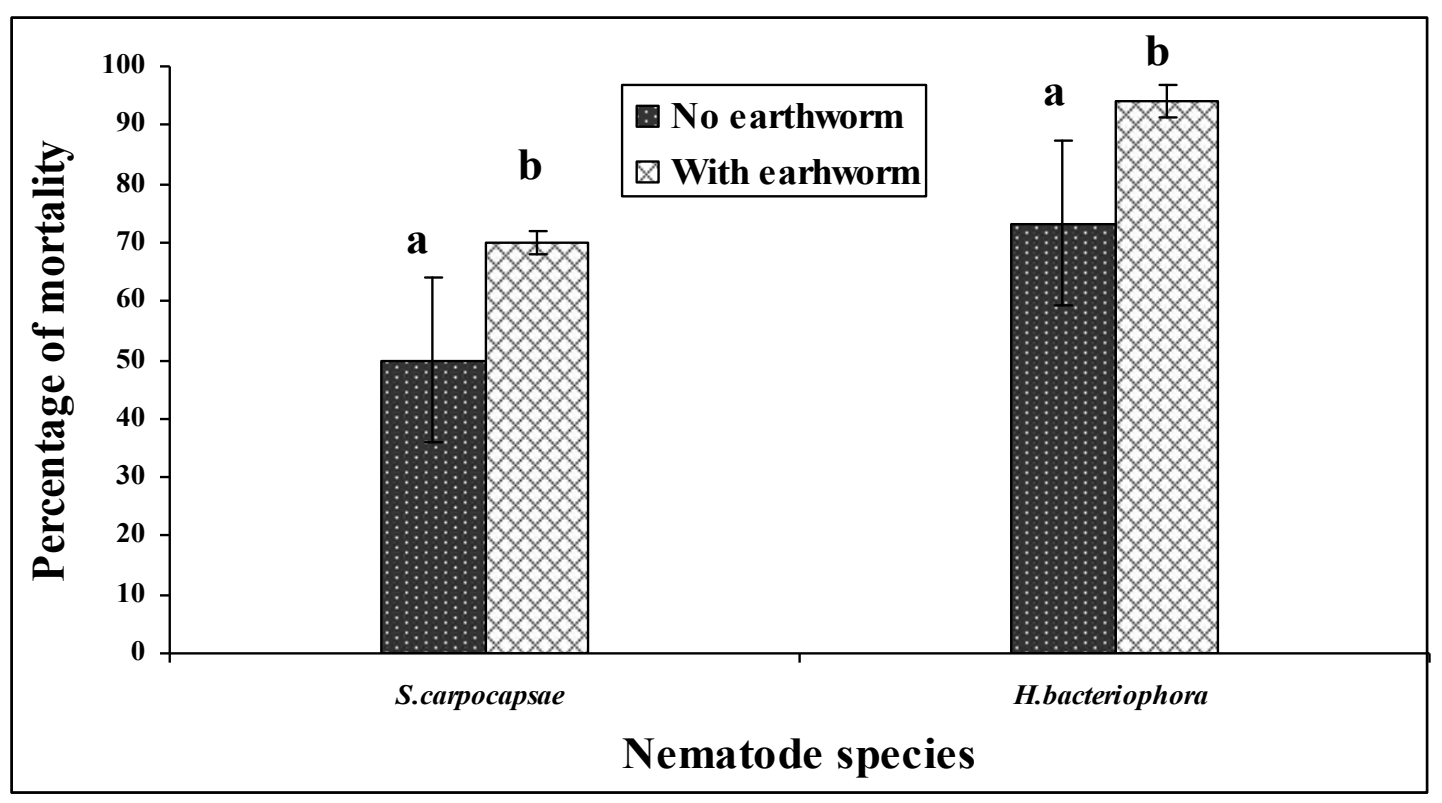

Fig. 1. Percentage of mortality caused by entomopathogenic nematodes infection of Spodoptera littoralis without (control) or with Allolobophora caliginosa 14 days posttreatment. The control contained only nematodes, S.carpocapsae (All strain) or $H$. bacteriophora (HP88) while treated contained nematodes and earthworm, Allolobophora caliginosa. Different letters above bars indicate statistically significant $(\mathrm{P} \leq 0.05)$.

Enhancing both $S$. carpocapsae and H.bacteriophora dispersal in the presence of earthworm A.caliginosa is a promising option to suppress economic damage resulting from the Egyptian cotton leafworm, S. littoralis. Further studies on entomogenous nematode dispersal in the presence of earthworm, are needed to confirm current findings.

\section{REFERENCES}

Adams, B. J.; Fodor, A.; Koppenhöfer, H. S.; Stackenbrand, T.E.; Stock, S.P.and Klein, M.G. (2006). Biodiversity and systematic of nematode-bacterium entomopathogens. Biol. Control 38:4-21.

Boemare, N. E. (2002). Biology, taxonomy and systematic of Photorhabdus and Xenorhabdus. Pp. 35-56 in R. Gaugler, ed. Entomopathogenic Nematology. Wallingford, UK: CABI Publishing.

Campbell, J. F.; Lewis, E.; Yoder, F. and Gaugler, R. (1995). Entomopathogenic nematode (Heterorhabditidae and Steinernematitidae) seasonal population dynamics and impact on insect populations in turf grass. Biol. Control 5 (4):598-606.

Capinera, J.L.; Blue, S.L. and Wheeler, G.S. (1982). Survival of earthworms exposed to Neoaplectana carpocapsae nematodes. J. Invertebr. Pathol. 39: 419-421.

Campos-Herrera, R.; Trigo, D. and Gutiérrez, C. (2006). Phoresy of the entomopathogenic nematode Steinernema feltiae by the earthworm Eisenia fetida. J. Invertebr. Pathol. 92: 50-54.

Downes, M.J. and Griffin, C.T. (1996). Dispersal behaviour and transmission strategies of the entomopathogenic nematodes Heterorhabditis and Steinernema. Biocontrol.Sci.Tech. 6:347-356. 
Edwards, C.A. (1983). Earthworm ecology in cultivated soils. In: Satchell (Ed.), Earthworm ecology from darwin to vermiculture. Chapman and Hall, London, pp.123-138.

Edwards, C.A. and Lofty, J. R. (1976). Biology of Earthworms. (1st edition), Chapman and Hall Ltd. London. Pp. 168-171.

Ekmen, Z.I.; Cakmak, I.; Karagoz, M. \& Hazir, S. (2010). Food preference of Sancassania polyphyllae (Acari: Acaridae): living entomopathogenic nematodes or insect tissues. Biocontrol Sci. Tech. 20:553-566.

Eng, M.S.; Preisser, E.L.; Strong, D.R. (2005). Phoresy of the entomopathogenic nematode Heterorhabditis marelatus by a non-host organism, the isopod Porcellio scaber. J. Invertebr. Pathol. 88,: 173-176.

Ferguson, C.S.; Schroeder P.C. and Shields E.J. (1995).Vertical distribution, persistence, and activity of entomopathogenic nematodes (Nematoda: Heterorhabditidae and Steinernematidae) in alfalfa snout beetle (Coleoptera: Curculionidae) infested fields. Environ. Entomol. 24:149-158.

Gaugler, R. (1981). Biological control potential of Neoaplectanid nematodes. J.Nematol. 13:241-249.

Georgis, R. and Poinar, G. O.(1983). Effect of soil texture on the distribution and infectivity of Neoaplectana carpocapsae (Nematoda: Steinernematidae). J.Nematol.15:308-311.

Georgis, R.; Koppenhöfer, A.M.; Lacey, L.A.; Bélair, G.; Duncan, .LW, Grewal, P.S; Samish, M.; Tan, L.; Torr, P.and van Tol, R.W.H.M. (2006). Successes and failures in the use of parasitic nematodes for pest control. Biol. Control:38:103123.

Hussein, M.A. (2004). Utilization of Entomopathogenic nematodes for the biological control of some lepidopterous pests. Ph.D. Thesis, Entomology Dept., Fac. Sci., Ain Shams Univ., Egypt, pp. 203.

Ibrahim, B.U.; Auta, J. and Adebote, D.A. (2010). Effects of soil types and enhanced nutrient levels of the productivity of earthworm (Eudrilius eugeniae, Kinberg). Bayero J. Pure Appl. Sci. 3(1) : 59-62.

Kaya, H.K. and Stock, S.P. (1979). Techniques in insect nematology. Pp. 281324 in L. A. Lacey, ed. Manual of Techniques in Insect Pathology. San Diego, CA: Academic Press.

Kaya, H.K. and Gaugler, R. (1990). Entomopathogenic nematodes in biological control. Appl. Soil Ecol.. 4: 93-115.

Kaya, H.K.; Aguillera, M.M.; Alumai, A. ; Choo, H.Y. ; de la Torre, M. ; Fodor, A. ; Gauguly, S.; Hazi, S.; Lakatos, T.; Pye, A.; Wilson, M.; Yamanaka, S.; Yang, H. and Ehlers, R.U. (2006). Status of entomopathogenic nematodes and their symbiotic bacteria from selected countries or regions of the world. Biol. Control 38: 134 -155.

Koppenhofer, A.M. and Kaya, H.K. (1996). Coexistence of two steinernematid nematode species ( Rhabditia : Steinernematidia ) in the presence of two host species: Appl. Soil Ecol. 4: 221-230.

Koppenhöfer, A.M. and Fuzy, E.M. (2006). Effect of soil type on infectivity and persistence of the entomopathogenic nematodes Steinernema scarabaei, Steinernema glaseri, Heterorhabditis zealandica, and Heterorhabditis bacteriophora. J. Invertebr. Pathol. 92: 11-22.9.

Kruitbos, L.M.; Heritage, S. and Wilson, M.J. (2009). Phoretic dispersal of entomopathogenic nematodes by Hylobius abietis. Nematology 11,:419-427. the sheep blowfly Lucilia cuprina. Nematologica 30: 358-365. 
Molyneux, A.S. and Bedding, R.A.(1984). Influence of soil texture and moisture on the infectivity of Heterorhabditis sp. D1 and Steinernema glaseri for larvae of the sheep blowfly Lucilia cuprina. Nematologica 30: 358-365.

Nuutinen, V.; Tyni-Juslin, J.; Vaenninen, I.and Vainio, A. (1991). The effects of four entomopathogenic fungi and an entomoparasitic nematode on the hatching of earthworm (Aporrectodea caliginosa) cocoons in the laboratory. J.Invertebr,Pathol. 58: 147-149.

Poinar, G.O. (1978). Associations between nematodes (Nematoda) and Oligochaetes (Annelida). Proc. Helminthol. Soc. Wash. 45: 202-210.

Poinar, G.O. and Hom, A. (1986). Survival and horizontal movement of infective stage Neoaplectana carpocapsae in the field. J. Nematol. 18: 34-36.

Potter, D.A.; Spicer, P. G.; Redmond, C. T. and Powell, A. J. (1994). Toxicity of pesticides to earthworms in Kentucky bluegrass turf. Bull. Environ. Contam. Toxicol. 52: 176-181.

Saleh, M.M.E. and Ragab, Z.A. (1999). Susceptibility of Spodoptera littoralis (Boisd) and Agrotis ipsilon (Hufn.) larvae to Egyptian and imported entomopathognic nematodes, Egyptian J. Appl. Sci, 14: 213-223.

Shapiro, D.I. ; Berry, E.C. and Lewis, L.C.(1993). Interactions between nematodes and earthworms: enhance dispersal of Steinernema carpocapsae. J. Nematol. 25 (2):189-192.

Shapiro, D.I.; Tylka, G.L.; Berry, E.C. and Lewis, L.C. (1995). Effects of earthworms on the dispersal of Steinernema spp. J. Nematol. 27 (1): 21-28.

Shapiro-Ilan, D.I. and Brown, I. (2013). Earthworms as phoretic hosts for Steinernema carpocapsae and Beauveria bassiana: Implications for enhanced biological control. Biol Control. 66, : 41-48.

Schroeder, W. J. and Beavers, J. B. (1987). Movement of the entomogenous nematodes of the families Heterorhabditidae and Steinernematidae in soil. J. Nematol. 19(2):257-259.

Smits, P.H. (1996). Post-application persistence of entomopathogenic nematodes. Biocontrol Sci. Tech. 6: 379-387.

Snedecor, G.W. (1966). Statistical Methods, Iowa State University press, Ames, Iowa, U.S.A. 53p.

Southey, J.F. (1986). Laboratory Methods for work with plant and soil nematodes. London: Ministry of Agriculture, $402 \mathrm{p}$.

Sturhan D. and Mracek, Z. (2000). Comparison of the Galleria baiting technique and a direct extraction method for recovering Steinernema infective stage juveniles from soil. Folia Parasitologica, 47: 315-318.

Timper, P.; Kaya, H.K and Gaugler, R. (1988). Dispersal of the entomogenous nematode Steinernema feltiae (Rhabditida: Steinernematidae) by infected adult insects. Environ Entomol. 17: 546-550.

Wang, Q.L.; Cui., J.Y. Li., Z.X. and Liu C.Q.(1995). Effect of soil moisture on the motion of Steinernema glaseri (Nematoda Steinernematidae). Chinese J. Biol. Control 11:150-152.

Westerweman, P.R. ( 1995). Comparative vertical migration of twenty one isolates of the insect parasitic nematode Heterorhabditis sp. in sand at $20 \mathrm{C}^{\circ}$. Fundam. Appl. Nematol. 18: 149-158.

Woodring, J. and Kaya, H.K. (1988). Steinernematid and heterorhabditid nematodes: A handbook of biology and techniques. Southern Cooperative Series Bulletin 331, 30 pp, Arkansas Agricultural Experiment Station, Fayetteville, AR. 
الملخص العربى

دور دودة الأرض Allolobophora caliginosa في تحسين المكافحة الحيوية لدودة ورق القطن الكبيرة Steinernema carpocapsae بواسطة نيماتودا الحشرات Spodoptera littoralis Boisd Heterorhabditis bacteriophora بنيماتودا

\author{
أحمد محمد على الايب و ومضان محمد أحمد العشرى \\ قسم وقاية النبات ـ كلية الزراعة الاب - جامعة الزقازيق.
}

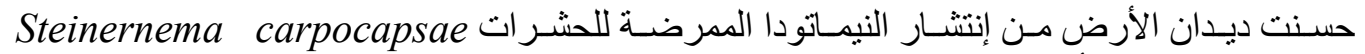

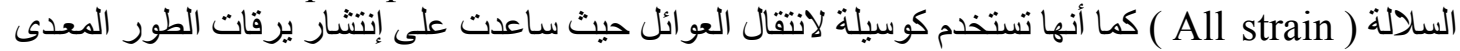

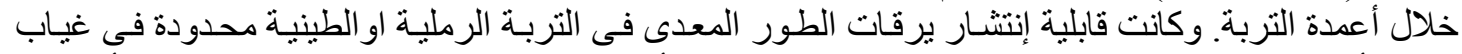

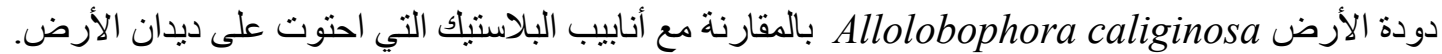

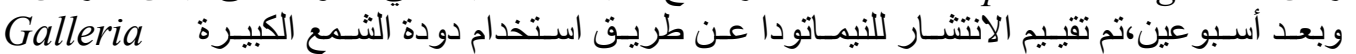
كellonella

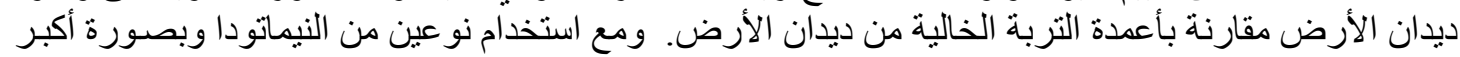

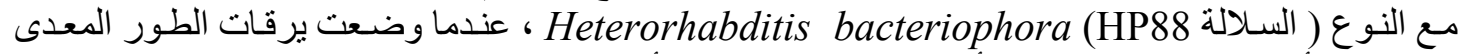

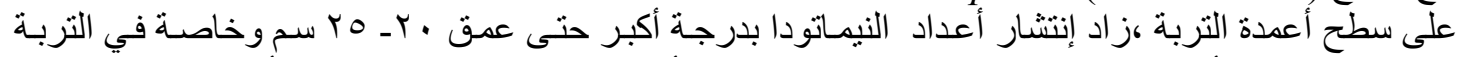

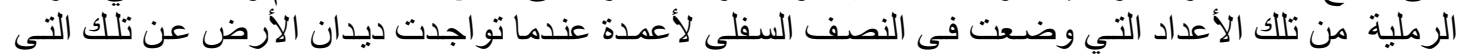

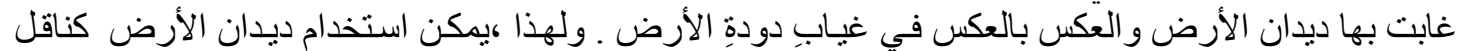

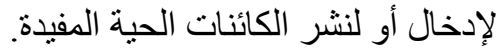

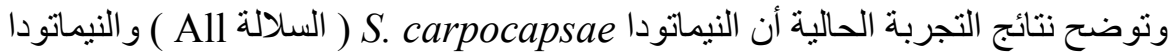

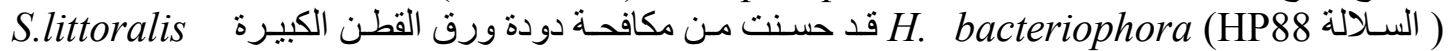

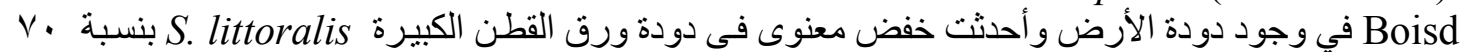

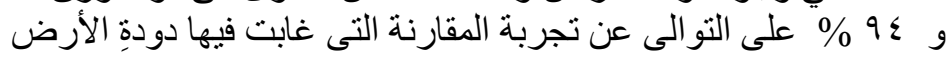

